\title{
Laboratory mice (Mus musculus, C57/BL 6J) do not exhibit fear in the presence of a rattlesnake
}

\author{
DAVID CHISZAR \\ University of Colorado, Boulder, Colorado 80302
}

\begin{abstract}
C57/BL 6J mice traversed as many squares during $5 \mathrm{~min}$ in an open field containing a rattlesnake (Crotalus enyo) as did control mice tested in the same open field without the snake. Additional mice were placed into quart jars and lowered into a cage containing six hungry rattlesnakes which exhibited great interest in the mice. Some of these mice simply observed the rattlesnakes while others observed the rattlesnakes killing and devouring mice. The open-field ambulation of these mice (with or without a rattlesnake in the open field) did not differ from the controls. Moreover, mice tested with a snake in the in field touched the snake (particularly the rattle) an average of four times during the 5-min trial. It vas concluded that these mice exhibit no obvious signs of fear in the presence of a rattlesnake.
\end{abstract}

It has been rumored by ophioculturists that laboratory mice show little or no fear when they are offered to either poisonous snakes or constrictors. This view is especially interesting because fear reactions have been noted in various birds (Grinnell \& Grinnell, 1907; Snith, 1946) and in at least two mammals: (1) California ground squirrels (Citellus beecheyi; Fitch, 1948; Linsdale, 1946) and (2) black-tailed prairie dogs (Cynomys ludovicianus; Osborn \& Allan, 1949). The absence of "snake fear" in inbred laboratory mice might indicate either that such behavior was bred out of the strain(s) and/or that "snake fear" is acquired through some sort of experience which laboratory mice do not receive. Before pursuing these lines of speculation, it was decided to determine if, in fact, "snake fear" is absent in a strain of laboratory mice.

\section{METHOD}

\section{Subjects}

Twenty-three adult (80-100 days old) C56/BL 6J mice, selected without regard for sex, were employed in this experiment. Prior to this study, the animals were maintained (since puberty) as breeding pairs in standard mouse cages (26.0 $x 13.5 \times 10 \mathrm{~cm})$. On the day of service in the experiment, a mouse was removed from its home cage, placed in a transfer cage $(35.5 \times 24.5 \times 10 \mathrm{~cm})$ with about 10 additional animals, and carried from the colony room to the laboratory.

\section{Apparatus and Procedure}

Each mouse was placed into the center of a plywood open field $(100 \times 100 \times 90 \mathrm{~cm})$, the floor of which was marked off into $3616.5-\mathrm{cm}$ squares. A trial lasted $5 \mathrm{~min}$, and the number of squares traversed was recorded after each minute. For eight mice (the control group), the open field was empty and had been cleaned just proor to the trial. For six mice (Experimental Group 1), the open field contained a rattlesnake (Crotalus enyo, approximately $45 \mathrm{~cm}$ ) known to be a mouse eater. (He had consumed an average of two mice per week for the preceding 2 months. However, this animal never struck a mouse in the open field; yet, he did rattle and rear his head.)

This paper is sponsored by Raymond C. Miles, who takes full editorial responsibility for its contents.
Table 1

Mean Ambulation Scores on Each Minute of the Open-Field Trial for Each Group of Mice

\begin{tabular}{|c|c|c|c|c|c|c|c|}
\hline \multirow[b]{2}{*}{ Group } & \multirow[b]{2}{*}{$\mathrm{n}$} & \multicolumn{5}{|c|}{ Successive Minutes } & \multirow{2}{*}{$\begin{array}{c}\text { Mean } \\
\text { for } \\
5 \mathrm{Min} \\
\end{array}$} \\
\hline & & 1 & 2 & 3 & 4 & 5 & \\
\hline Control & 8 & 25.3 & 39.7 & 36.0 & 32.6 & 40.0 & 173.7 \\
\hline Exp 1 & 6 & 36.5 & 38.3 & 42.5 & 32.8 & 35.8 & 186.0 \\
\hline Exp 2 & 3 & 22.3 & 46.3 & 34.6 & 32.6 & 38.3 & 174.3 \\
\hline Exp 3 & 3 & 26.6 & 38.0 & 40.3 & 30.0 & 28.3 & 163.3 \\
\hline \multirow[t]{3}{*}{ Exp 4} & 3 & 22.6 & 30.6 & 44.3 & 33.6 & 31.3 & 162.6 \\
\hline & \multicolumn{7}{|c|}{ Means Over All Experimental Groups } \\
\hline & 15 & 28.9 & 38.3 & 40.8 & 32.4 & 33.9 & 174.4 \\
\hline
\end{tabular}

Three additional experimental groups were employed; each had experience with rattlesnakes prior to the open field trial. The mice of Experimental Group $2(n=3)$ were placed into separate quart jars and lowered into a large cage containing six hungry rattlesnakes. The snakes showed considerable interest in the jars; they frequently flicked their tongues at the jars, and the tips of their tongues often touched the jar. However, no snake actually struck at a jar. After $30 \mathrm{~min}$, the mice were removed from the jars and were given an open field trial with the rattler in the apparatus. Mice of Experimental Groups 3 and 4 (ns $=3$ ) were treated like those of Experimental Group 2 except that, during the $30 \mathrm{~min}$ of rattlesnake pre-exposure, the snakes were in the process of killing and devouring approximately 10 additional mice. Mice of Experimental Group 3 were placed into the open field with the rattler while mice of Experimental Group 4 were run in the open field without the snake. The purpose of the latter group was to determine if the observation of killing exerted a general "fearfulness" effect upon open-field ambulation.

\section{RESULTS AND DISCUSSION}

Table 1 presents the mean number of squares traversed over successive minutes for each group. A 5 by 5 mixed ANOVA revealed an insignificant group main effect as well as an insignificant Group by Minute interaction (both Fs $<1.0$ ). The numerical increase in ambulation over successive minutes was statistically reliable $(\mathrm{F}=5.43$, $\mathrm{df}=4 / 72, \mathrm{p}<.01)$, indicating that exploratory behavior intensified over time. However, the absence of a Group by Minute 
interaction showed that the presence of a rattlesnake in the open field had no influence on the temporal organization of exploration. Thus, it was concluded that $\mathrm{C} 57 / \mathrm{BL} 6 \mathrm{~J}$ mice showed no fear of a rattlesnake and that such fear was not acquired by observing rattlesnakes (with or without prey) through a glass jar. In support of this conclusion, it should be noted that mice of Experimental Groups 1, 2, and 3 touched the rattlesnake an average of four times during their trials. These animals seemed particularly interested in the rattle since most of the contacts were made with this structure. (Although fecal boluses were not counted in this study, it is the experimenter's impression that the groups did not differ. Indeed, very few feces were deposited by any mouse.)

Since the C57/BL strain is well known for its high ambulation-exploration rate (McClearn, 1964), it would be appropriate to run the above tests on other strains (especially $\mathrm{C} 3 \mathrm{H}$ ) and on wild mice before the present conclusion is generalized. Perhaps C57/BL mice are highly active because they are not inhibited by stimuli which would evoke obvious fear responses in other strains or in wild mice.

It is puzzling that watching rattlers killing other mice did not induce our subjects to fear the rattler in the open field. Informal observations in this laboratory indicate that fear develops immediately in a mouse which is struck at but missed (i.e.. one-trial learning). Hence, it may be that predation directed at the "self" is the critical fear-inspiring experience and that other mice (regardless of spatial proximity) cannot serve as surrogate "selves." If this informal observation is borne out experimentally, the mouse-snake paradigm might be a useful situation in which to study the formation of biologically prepared associations (Seligman, 1970).

\section{REFERENCES}

Fitch. H. S. Ecology of the California ground squirrel on grazing lands. American Midland Naturalist. 1948. 39. 513-596. Grinnell. J.. \& Grinnell. H. W. Reptiles of Los Angeles County. California. Throop Institute Bulletin. 1907. 35. 1-64.

Linsdale. J. M. The California ground squirrel. Los Angeles: University of California Press. 1946.

McClearn. G. E. Genotype and mouse behavior. Genetics today: Proceedings of the XI International Congress of Genetics. New York: Pergamon. 1964. Pp. 795-805.

Osborn. B.. \& Allan, P. F. Vegetation of an abandoned prairie dog town in tall grass prairie. Ecology, 1949. 30. $322-332$.

Seligman. M. E. P. On the generality of the laws of learning. Psychological Review, 1970. 77. 406-418.

Sмiтн. H. M. Snake detection. Chicago Naturalist. 1946. 9. 63-69.

(Received for publication July 14, 1975.) 